Special Issue/Collection: Research Project PRIN-MIUR 2015

"The forest-wood value chain: biomass supply, traceability, C-footprint. Innovation for bioarchitecture and energy efficiency"

Guest Editors: Scarascia Mugnozza G, Maesano M, Romagnoli M

\title{
Hardness and contact angle of thermo-treated poplar plywood for bio- building
}

\author{
Roberto Zanuttini, \\ Francesco Negro, \\ Corrado Cremonini
}

The interest towards poplar cultivation and its wood has recently been growing in Italy, where the use of timber and wood-based materials in construction is increasing as well. Poplar plywood, with a national production of around $270,000 \mathrm{~m}^{3}$ in 2017 , is a key product for the Italian wood sector, and currently is destined for several applications as component for furniture and motorhomes. Previous research has shown that thermal treatment can be effectively applied to poplar plywood in order to make it suitable to the requirements of new end-uses. The present study aims to widen the knowledge of the effects of thermal treatment on poplar plywood. With this purpose, 7-layered, 12-mm thick plywood bonded with urea-melamine-formaldehyde (UMF) resin was thermally treated for $2 \mathrm{~h}$ at 170,190 and $210{ }^{\circ} \mathrm{C}$ through the Termovuoto ${ }^{\circledR}$ process. The treatment aimed to improve the dimensional stability and durability against fungal decay. The process was set at lower temperature and shorter time than those of many thermal treatments commonly used in practice in order to limit the reduction in mechanical properties and to maintain an adequate bonding quality. The above properties were already verified by previous research, whereas in this study Brinell hardness and contact angle of treated panels were investigated as relevant for several end-uses that can be prospected in building and in outdoor environments. Brinell hardness decreased from 10.8 to $8.3 \mathrm{~N} \mathrm{~mm}^{-2}$ and contact angle increased from $75.8^{\circ}$ to $103.6^{\circ}$. Overall, treatment at $190{ }^{\circ} \mathrm{C}$ seems the most suitable to induce balanced modifications in the panels. From a technical point of view, these appear ready to enter the market, for instance for use in exterior claddings, partitions and outdoor flooring.

Keywords: Brinell Hardness, Contact Angle, Plywood, Poplar, Thermo-treatment

\section{Introduction}

The interest towards the use of wood in construction has been growing steadily in the last two decades. This can be attributed mainly to the development of innovative wood-based and engineered products that have considerably widened the range

DISAFA, University of Torino, l.go Paolo Braccini 2, I-10095 Grugliasco, TO (Italy)

\section{@ Francesco Negro}

(francesco.negro@unito.it)

Received: Sep 29, 2020 - Accepted: Apr 08, 2021

Citation: Zanuttini R, Negro F, Cremonini C (2021). Hardness and contact angle of thermo-treated poplar plywood for biobuilding. iForest 14: 274-277. - doi: 10.3832/ ifor3662-014 [online 2021-05-29]

Communicated by: Giacomo Goli of architectural timber solutions (Jeska \& Pascha 2014). Moreover, the environmental value of wood materials, in terms of low greenhouse gas emissions associated to their production, carbon dioxide storage, easiness of reuse etc., is ideal to meet the sustainability requirements set by the modern bio-building (Bergman et al. 2014, Negro \& Bergman 2019).

The Italian construction sector is in line with this global interest towards wood and derived products. According to FederlegnoArredo (2020), Italy was the fourth European producer of prefabricated timber buildings in 2018; 3144 buildings were constructed on the national territory with a turnover of 724 million euros, which represents a $5 \%$ increase compared to 2017. New timber buildings were mainly residential ( $91 \%$, that is $7 \%$ of new dwellings), whereas non-residential buildings constituted the remaining minor share ( $9 \%$ ).

The poplar supply chain is a key factor for the Italian wood sector given the annual volume of timber that was estimated 2.25 million $\mathrm{m}^{3}$ in 2014 (FederlegnoArredo 2014).
After decades characterized by a constant decrease in plantation coverage and operators (Assopannelli 2014), a renewed interest in poplar cultivation and its wood has re-emerged recently: the amount of plantations has been growing since 2015, reaching 46,125 ha in 2017 (Corona et al. 2018). This tendency is also due to the increased support from the Regions and the central government, as shown by several activities: the constitution of the National Poplar Observatory; the signature of the "Agreement for the development of the poplar supply chain" among Northern Regions where plantations are more diffuse; the compilation of an inventory of the Italian poplar cultivation (Monipoplar project); the publication of the "Guidelines for a sustainable poplar cultivation" (Corona et al. 2018).

Poplar wood is a versatile raw material that has many applications ranging from energy to construction. The national poplar cultivation sector is mainly geared towards producing assortments suitable for plywood manufacturing, which represents the 
higher valorization of poplar wood and timber. In 2017, the Italian production of poplar plywood reached about $270,000 \mathrm{~m}$ (EPF 2018). Currently, this product is mainly destined to furniture, but a sizable proportion is also used in packaging, transport, do-it-yourself and construction.

Thermal treatment is widespread at the global level as an effective process to increase the dimensional stability and decay durability of wood (Esteves \& Pereira 2009 Candelier et al. 2016). Generally, the treat ment is made on solid wood (sawn timber, sliced or rotary cut veneers). Four industries are active in Italy in the field of thermal modification technologies and severa plants have been established at the national level (Goli et al. 2019). In recent years various studies have investigated the effects of thermal treatment on the properties of poplar wood and derived products, taking into account solid wood (Marcon et al. 2018), veneers (Castro et al. 2016, Sandak et al. 2016), oriented strand board (Cetera et al. 2018) and plywood (Goli et al. 2014, Rosso et al. 2016). In particular, Zanuttini et al. (2020) investigated the effect of thermal treatment on poplar plywood by characterizing its density, bending strength, modulus of elasticity, bonding quality, color change and decay durability. Thermal treatment can broaden the applications of this panel, in particular with regard to non-structural uses in exterior environments under cover or exposed to the weather with limited wetting conditions (use classes UC 2 and UC 3.1, according to EN-335 2013). Poplar wood on its own, in fact, is not suited for applications in these exposures due to its low durability (class "DC 5 - not durable", according to EN-350 2016).

The present study aims at widening the knowledge of the effects of thermal treatment on poplar plywood. To this purpose, poplar plywood was treated in a range of 170 to $210{ }^{\circ} \mathrm{C}$ for $2 \mathrm{~h}$. In this work, temperatures were selected in the low-mid range of those commonly used, but different process parameters can be worth studying as well. The treatment aimed to improve the dimensional stability and decay durability of the panels while limiting the reduction in their mechanical properties and maintaining adequate color and bonding quality, which was already verified by Zanuttini et al. (2020). In this study, Brinell hardness and contact angle of thermotreated poplar plywood have been investigated as relevant properties for assessing its use in different applications in building.

\section{Materials and methods}

A detailed description of the poplar plywood subjected to testing and of the thermal treatment applied is reported in Zanuttini et al. (2020). In brief, the experimental activity was performed on 7-layered, $12 \mathrm{~mm}$ thick poplar (I-214 clone) plywood with dimensions $2500 \times 1200 \mathrm{~mm}$ produced at industrial scale in a plywood mill located in northwest Italy. Panels were bonded using a commercial urea-melamine-formaldehyde (UMF) resin suited for meeting the requirements of Class 2 according to the specifications of the EN-636 (2015). Plywood was thermo-treated for $2 \mathrm{~h}$ at $170^{\circ} \mathrm{C}$ (T1), $190^{\circ} \mathrm{C}(\mathrm{T} 2)$ and $210{ }^{\circ} \mathrm{C}$ (T3) by means of the Termovuoto ${ }^{\circledR}$ process (Allegretti et al. 2012). Treating the entire plywood was preferred to treating veneers prior to composition because thermo-treated veneers are more brittle and their reduced hygroscopicity can hinder the subsequent bonding phase. Panels average density and mass losses (ML) due to thermal treatment correspond to those already reported in $\mathrm{Za}$ nuttini et al. (2020): To: $388 \mathrm{~kg} \mathrm{~m}^{-3} ; \mathrm{T} 1: 381$ $\mathrm{kg} \mathrm{m}^{-3}, \mathrm{ML}=1.8 \%$; $2: 358 \mathrm{~kg} \mathrm{~m}^{-3}, M L=7.7 \%$; T3: $353 \mathrm{~kg} \mathrm{~m}^{-3}, M L=9.0 \%$.

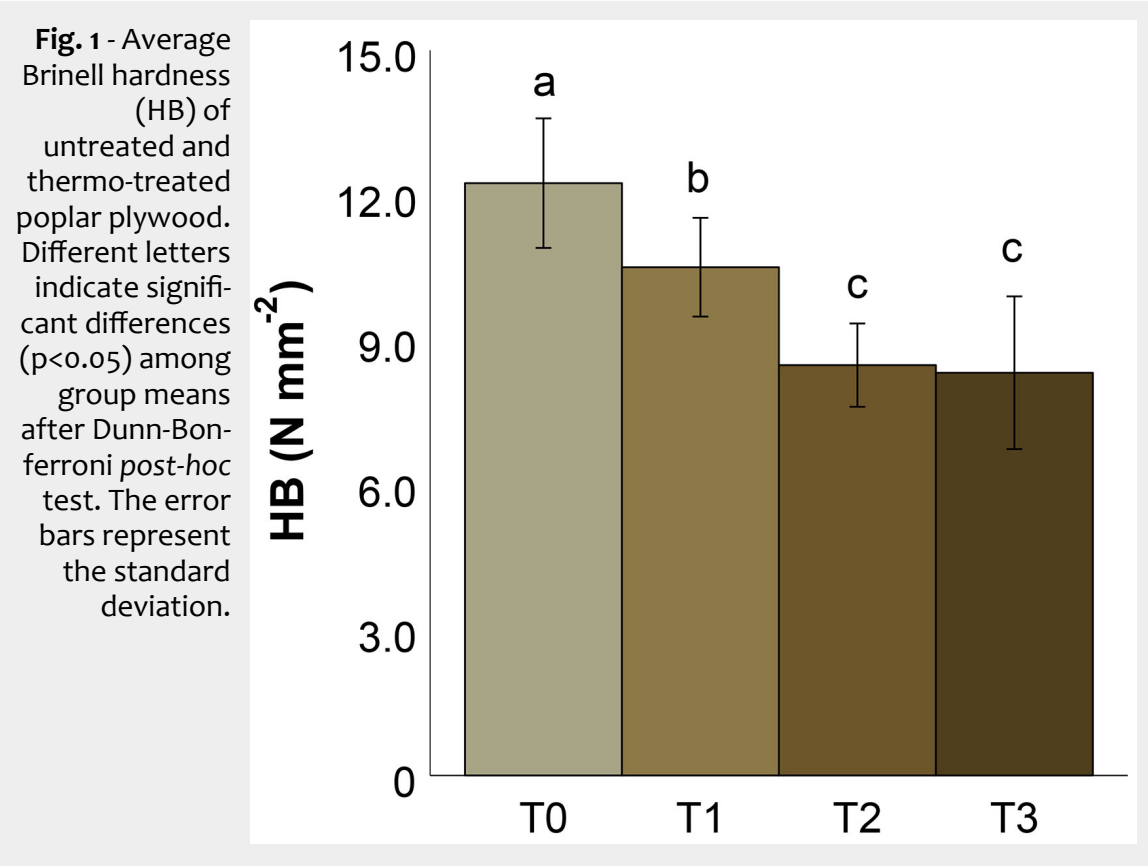

Overall, twelve panels were randomly sampled from the same batch of 150 panels. Nine of these were thermo-treated (three panels $\times$ three temperature treatments), whereas three untreated panels (To) were used as control. Specimens were cut and conditioned at $20{ }^{\circ} \mathrm{C}$ and $65 \%$ relative humidity until the equilibrium moisture content was reached.

Brinell hardness (HB) was determined on 10 randomly cut specimens $(50 \times 50 \times 12$ $\mathrm{mm})$ per panel type according to EN-1534 (2020). One kN load was applied for $25 \pm 5$ $s$ on each specimen through a steel ball indenter with diameter $10 \pm 0.01 \mathrm{~mm}$, and Brinell hardness was calculated as follows (eqn. 1):

$$
H B=\frac{2 F}{\pi \cdot D \cdot\left[D-\sqrt{D^{2}-d^{2}}\right]}
$$

where $H B$ is the hardness (in $\mathrm{N} \mathrm{mm}^{-2}$ ), $\mathrm{F}$ is the maximum load applied (in N), D is the diameter of the ball (in $\mathrm{mm}$ ) $d$ is the diameter of the residual indentation (in $\mathrm{mm}$ ).

Diameters of residual indentation were measured using a stereo microscope Leica M205 C (resolution $1050 \mathrm{lp} \mathrm{mm}^{-1}$, which being apt to structures down to $476 \mathrm{~nm}$ is suitable to measure HB indentation according to eqn. 1) and the software Leica Application Suite (Leica AG, Wetzlar, Germany).

Contact angle was determined on 40 randomly cut specimens $(50 \times 50 \times 12 \mathrm{~mm})$ per panel type by means of the static sessile drop method using droplets of distilled water with volume $10 \mu$ l. Images were collected after $2 \mathrm{~s}$ from droplets released using a stereo microscope equipped with a camera. Images were processed through the software Photoshop ${ }^{\circledR}$ Elements ver. 11 (Adobe Inc., San José, CA, USA). The contact angle was measured using the plugin "Contact angle" developed by M. Brugnara for the software ImageJ (National Institutes of Health, USA - William et al. 2010).

The statistical analysis was performed using the software package SPSS ${ }^{\circledR}$ ver. 25.0 (IBM Corp., Armonk, NY, USA). Differences in contact angle between untreated and thermo-treated plywood were investigated through the Kruskal-Wallis non-parametric test, with the Dunn-Bonferroni test as a post-hoc. Differences in Brinell hardness were investigated by one-way analysis of variance (ANOVA) and LSD test as a posthoc. Homogeneity of variance was verified by Levene's test; significance was always set at a level of 0.05 .

\section{Results and discussion}

Brinell hardness of untreated and thermo-treated poplar plywood is illustrated in Fig. 1. Three groups were identified through LSD post-hoc test: To, T1, and T2-T3 $(p=0.776)$, with differences between groups always significant $(p<0.005)$. Compared to To, HB decreased as follows: $\mathrm{T} 1=$ $-12.2 \%, \mathrm{~T}_{2}=-30.9 \%, \mathrm{~T}_{3}=-32.5 \%$. As for other mechanical properties, the reduction in $\mathrm{HB}$ can be related to the mass loss due to thermal treatment, as already reported in stud- 
ies on poplar wood and other hardwoods (Sedlar et al. 2019). Decrease in HB can also be related to the reduction in modulus of elasticity that is typically induced by thermal treatment. In Brinell Hardness test, in fact, once the load is released wood springs back to some extent due to partial elastic recovery (Sydor et al. 2020). Lower modulus of elasticity attenuates this effect, resulting in wider indentation and consequently in lower $\mathrm{HB}$ values (eqn. 1).

Non-significant differences between $\mathrm{T}_{2}$ and $\mathrm{T} 3$ can be explained by the limited difference in mass loss due to thermal treatment (T2: 7.7\%, T3: 9.0\% - see above). In addition, non-significant differences could also be due to local collapses determined by the increasing brittleness of wood that could have affected the extension of the indentation area. Overall, considering that poplar wood is among the woods with lower hardness (CIRAD 2015), the reduction in $\mathrm{HB}$ due to thermal treatment can constitute a critical aspect for some end applications.

Fig. 2 shows the measured values of contact angle. Two groups were identified through the Dunn-Bonferroni post-hoc test: To and T1-T2-T3. Differences between groups were always significant $(p<0.001)$, whereas differences among $\mathrm{T}_{1}, \mathrm{~T}_{2}$ and $\mathrm{T}_{3}$ resulted always not significant $(p>0.700)$. Compared to To, the contact angle of T1-T2T3 was about $34 \%$ higher. This result is also attributable to the degradation of hemicelluloses and lignocellulosic components of wood, which is known to be the main cause of the increased hydrophobicity of thermo-treated wood (Miklečić \& JiroušRajković 2016). Results are consistent with those obtained by Hakkou et al. (2005), who found that contact angle increased and remained constant for thermal modifications performed at temperatures higher than $120^{\circ} \mathrm{C}$. The non-significant differences among $\mathrm{T}_{1}, \mathrm{~T}_{2}$ and $\mathrm{T}_{3}$ could also be explained by the close difference in intensity of the treatments performed (temperature increased by steps of $20^{\circ} \mathrm{C}$ ) that induced similar modifications in the chemical composition of the surface of thermo-treated plywood. This interpretation is in line with the results of a previous study by Unsal et al. (2011). In this study, non-significant differences were found in contact angle of eucalyptus wood treated at $150{ }^{\circ} \mathrm{C}$ and 180 ${ }^{\circ} \mathrm{C}$, indicating that $30{ }^{\circ} \mathrm{C}$ difference in treatment temperature does not necessarily affect the contact angle value. In addition, other studies have found that mass loss and reduction in wettability are not correlated (Esteves \& Pereira 2009).

Finally, Tab. 1 provides an overview on the physico-mechanical properties of poplar plywood treated at $190^{\circ} \mathrm{C}$ for $2 \mathrm{~h}(\mathrm{~T} 2)$ through the Termovuoto ${ }^{\circledR}$ process.

\section{Conclusion}

The need for sustainable construction constitutes a major opportunity for woodbased products. Thermal treatment can

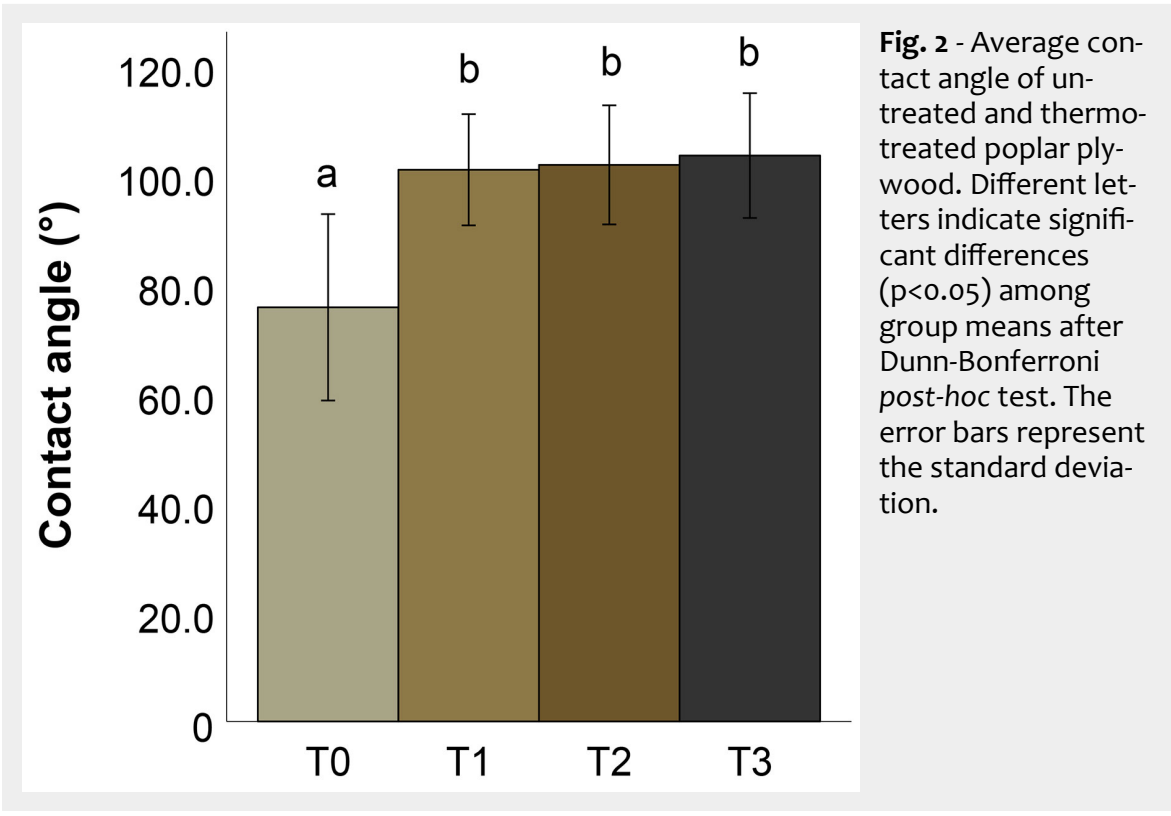

open new applications to poplar plywood, making it suitable for use in covered exterior or exterior environments where adequate decay durability is required. This is also interesting for promoting local supply chains and avoiding the use of chemical preservatives with higher environmental impact.

Basing on previous research carried out by the authors, in this study the treatment intensity was chosen in order to obtain a final product with balanced modifications. Reduction in Brinell Hardness ranged from about $12 \%$ to $30 \%$, and contact angle increased of about 34\%.

The results of this study widen the knowledge of the properties of thermo-treated

poplar plywood. Overall, from a technical point of view and considering that it meets the requirements of bonding quality of the reference standard, the product appears ready to enter the market, with particular regard to plywood treated at $190{ }^{\circ} \mathrm{C}$. This, considering the value added of thermal treated poplar plywood, could also contribute to sustaining the recent renewed interest towards poplar cultivation in Italy.

\section{Acknowledgements}

Part of the experimental activity was performed in collaboration with Dr. Gaetano Castro, CREA-Research Centre for Forestry and Wood.

Tab. 1 - Physico-mechanical properties of poplar plywood thermo-treated at $190^{\circ} \mathrm{C}$ for $2 \mathrm{~h}$ through the Termovuoto ${ }^{\oplus}$ process. (a): values of Brinell hardness and contact angle derive from the present study; (b): values of density, bending strength (MoR), Modulus of Elasticity (MoE), bonding quality and decay durability are taken from Zanuttini et al. (2020).

\begin{tabular}{|c|c|c|c|}
\hline Properties & $\begin{array}{l}\text { Reference } \\
\text { standard }\end{array}$ & Unit & Mean \pm st.dev \\
\hline Brinell hardness ${ }^{a}$ & $\mathrm{EN}-1534$ & $\mathrm{~N} \mathrm{~mm}^{-2}$ & $8.5 \pm 0.9$ \\
\hline Contact angle $^{a}$ & - & degrees & $101.9 \pm 10.9$ \\
\hline Density ${ }^{b}$ & EN-323 & $\mathrm{kg} \mathrm{m}^{-3}$ & $358 \pm 7.1$ \\
\hline MoR ${ }^{\mathrm{b}}$ longitudinal & $\mathrm{EN}-310$ & $\mathrm{~N} \mathrm{~mm}^{-2}$ & $27.7 \pm 3.0$ \\
\hline MoR ${ }^{\mathrm{b}}$ transversal & EN-310 & $\mathrm{N} \mathrm{mm}^{-2}$ & $29.8 \pm 4.7$ \\
\hline MoE ${ }^{\mathrm{b}}$ longitudinal & $\mathrm{EN}-310$ & $\mathrm{~N} \mathrm{~mm}^{-2}$ & $3840 \pm 190$ \\
\hline MoE ${ }^{\mathrm{b}}$ transversal & EN-310 & $\mathrm{N} \mathrm{mm}^{-2}$ & $3350 \pm 100$ \\
\hline Bonding quality - Shear strength ${ }^{b}$ & EN-314, Class 2 & $\mathrm{~N} \mathrm{~mm}^{-2}$ & $1.07 \pm 0.3$ \\
\hline Bonding quality - Fiber release ${ }^{b}$ & EN-314, Class 2 & $\%$ & $76 \pm 30$ \\
\hline Decay durability ${ }^{\mathrm{b}}-$ C. puteana & EN-12038 & Clx. & 1 \\
\hline Decay durability ${ }^{\mathrm{b}}$ - G. trabeum & EN-12038 & Clx. & 1 \\
\hline Decay durability ${ }^{b}-T$. versicolor & EN-12038 & Clx. & 4 \\
\hline Decay durability ${ }^{\mathrm{b}}-P$. ostreatus & EN-12038 & Clx. & 4 \\
\hline
\end{tabular}




\section{References}

Allegretti O, Brunetti M, Cuccui I, Ferrari S, Nocetti M, Terziev N (2012). Thermo-vacuum modification of spruce (Picea abies Karst.) and fir (Abies alba Mill.) wood. BioResources 7 (3): 3659-3669. - doi: 10.15376/biores.7.3.3659-3669 Assopannelli (2014). Declino della pioppicoltura in Italia e raccomandazioni per una strategia di rilancio [Decline of poplar cultivation in Italy and recommendations for a relaunching strategy]. Assopannelli, Milano, Italy, pp. 63. [in Italian]

Bergman R, Puettman M, Taylor A, Skog K (2014). The carbon impacts of wood products. Forest Products Journal 64 (7/8): 220-231. - doi: 10.13073/FPJ-D-14-00047

Candelier K, Thevenon MF, Petrissans A, Dumarcay S, Gerardin P, Petrissans M (2016). Control of wood thermal treatment and its effects on decay resistance: a review. Annals of Forest Sciences 73: 571-583. - doi: 10.1007/s13595-016-054 $1-x$

Castro G, Rosso L, Allegretti O, Cuccui I, Cremonini C, Negro F, Zanuttini R (2016). Influence of thermo-vacuum treatment on bending properties of poplar rotary-cut veneer. iForest 10 : 161-163. - doi: 10.3832/ifor1955-009

Cetera P, Negro F, Cremonini C, Todaro L, Zanuttini $R$ (2018). Physico-mechanical properties of thermally treated poplar OSB. Forests 9 (6): 345. - doi: $10.3390 / f 9060345$

CIRAD (2015). Tropix 7. The main technological characteristics of 245 tropical wood species. Technical sheets available, Temperate areas, Web site. [online] URL: http://tropix.cirad.fr/en/ technical-sheets-available

Corona P, Bergante S, Castro G, Chiarabaglio PM, Coaloa D, Facciotto G, Gennaro M, Giorcelli A, Rosso L, Vietto L, Nervo G (2018). Linee di indirizzo per una pioppicoltura sostenibile [Guidelines for a sustainable poplar cultivation]. Rete Rurale Nazionale, Consiglio per la ricerca in agricoltura e l'analisi dell'economia agraria, Roma, Italy, pp. 63. [in Italian] [online] URL: http://www.reterurale.it/flex/cm/pages/ServeB LOB.php/L/IT/IDPagina/18732

EN-314-2 (1993). Plywood. Bonding quality. Part 2: Requirements. CEN, European Committee for Standardization, Brussels, Belgium, pp. 6. [online] URL: http://standards.cen.eu/dyn/www /f?p=CENWEB:105

EN-323 (1993). Wood-based panels. Determination of density. CEN, European Committee for Standardization, Brussels, Belgium, pp. 10. [on- line] URL: http://standards.cen.eu/dyn/www/f? $\mathrm{p}=$ CENWEB:105

EN-335 (2013). Durability of wood and woodbased products - Use classes: definitions, application to solid wood and wood-based products. CEN, European Committee for Standardization, Brussels, Belgium, pp. 14. [online] URL: https://standards.cen.eu/dyn/www/f? $\mathrm{p}=$ CENWEB:105

EN-350 (2016). Durability of wood and wood based products. Testing and classification of the durability to biological agents of wood and wood-based materials. CEN, European Committee for Standardization, Brussels, Belgium, pp. 70. [online] URL: https://standards.cen.eu/dyn/ $w w w / f ? p=C E N W E B: 105$

EN-636:2012+A1 (2015). Plywood. Specifications. CEN, European Committee for Standardization, Brussels, Belgium, pp. 16. [online] URL: https:// standards.cen.eu/dyn/www/f?p=CENWEB:105

EN-1534 (2020). Wood flooring and parquet. Determination of resistance to indentation. Test method. CEN, European Committee for Standardization, Brussels, Belgium, pp. 10. [online] URL: https://standards.cen.eu/dyn/www/f? $p=C E$ NWEB:105

EPF (2018). Annual Report 2017-2018. European Panel Federation, Brussels, Belgium, pp. 263. Esteves BM, Pereira HM (2009). Wood modification by heat treatment: a review. Bioresources 4 (1): 370-404. - doi: 10.15376/biores.4.1.370-404 FederlegnoArredo (2014). Intesa per lo sviluppo della filiera del pioppo [Agreement for the development of the poplar supply chain]. Federlegnoarredo, Venice, Italy, pp. 16. [in Italian] FederlegnoArredo (2020). $4^{\circ}$ Rapporto case ed edifici in legno $\left[4^{\text {th }}\right.$ report timber houses and buildings]. FederlegnoArredo, Milan, Italy, pp. 37. [in Italian]

Goli G, Cremonini C, Negro F, Zanuttini R, Fioravanti M (2014). Physical-mechanical properties and bonding quality of heat treated poplar and ceiba plywood. iForest 8: 687-692. - doi: 10.3832/ifor1276-007

Goli G, Todaro L, Allegretti O, Romagnoli M (2019). Wood modification in Italy. In: "Wood modification in Europe. A state-of-the-art about processes, products and applications" (Jones D, Sandberg D, Goli G, Todaro L eds). Firenze University Press, Firenze, Italy, pp. 71-72. [online] URL: http://fupress.com/catalogo/woodmodification-in-europe/4008

Hakkou M, Pétrissans M, El Bakali I, Gérardin P, Zoulalian A (2005). Wettability changes and mass loss during heat treatment of wood. Holzforschung 59: 35-37. - doi: 10.1515/HF.2005.006

Jeska S, Pascha KS (2014). Emergent timber technologies. Materials structures engineering projects. Birkhäuser, Basel, Switzerland, pp. 175. - doi: 10.1515/9783038216162.170

Marcon B, Goli G, Matsuo-Ueda M, Denaud L, Umemura K, Gril J, Kawai S (2018). Kinetic analysis of poplar wood properties by thermal modification in conventional oven. iForest 11: 131139. - doi: 10.3832/ifor2422-010

Miklečić J, Jirouš-Rajković V (2016). Influence of thermal modification on surface properties and chemical composition of beech wood (Fagus sylvatica). Drvna Industrija 67 (1): 65-71. - doi: 10.5552/drind.2016.1520

Negro F, Bergman R (2019). Carbon stored by furnishing wood-based products: an Italian case study. Maderas - Ciencia y Tecnología 21 (1): 65-76. - doi: 10.4067/S0718-221X2019005000 106

Rosso L, Negro F, Castro G, Cremonini C, Zanuttini R (2016). Moisture dynamics of thermally treated poplar plywood. European Journal of Wood and Wood Products 75 (2): 277-279. - doi: 10.1007/s00107-016-1134-y

Sandak A, Allegretti A, Cuccui I, Sandak J, Rosso L, Castro G, Negro F, Cremonini C, Zanuttini R (2016). Thermo-vacuum modification of poplar veneers and its quality control. Bioresources 11 (4): 10122-10139. - doi: 10.15376/biores.11.4.1012210139

Sedlar T, Sinković T, Perić I, Jarc A, Stojnić S (2019). Hardness of thermally modified beech wood and hornbeam wood. Journal of the Forest Society of Croatia 9- 10: 425-433. - doi: 10.31298/sl.143.9-10.4

Sydor M, Pinkowski G, Jasinska A (2020). The Brinell method for determining hardness of wood flooring materials. Forests 11: 878. - doi: 10.3390/f11080878

Unsal O, Candan Z, Korkut S (2011). Wettability and roughness characteristics of modified wood boards using a hot-press. Industrial Crops and Products 34: 1455-1457. - doi: 10.1016/ j.indcrop.2011.04.024

William DL, Kuhn AT, Amann MA, Hausinger MB, Konarik MM, Nesselrode El (2010). Computerised measurement of contact angles. Galvanotechnik 10: 1-11.

Zanuttini R, Castro G, Cremonini C, Negro F, Palanti S (2020). Thermo-vacuum treatment of poplar (Populus spp.) plywood. Holzforschung 74 (1): 60-67. - doi: 10.1515/hf-2019-0049 